\title{
Experimental Investigations into Improvement of Cleaning Performance for Anticorrosive Paints for Shipbuilding using Handheld-Type Laser Cleaning Equipment
}

\author{
휴대용 레이저 클리닝 장비를 이용한 서로 다른 조선용 방청도료의 \\ 클리닝 성능 향상을 위한 실험적 연구
}

Ji-Eon Kim*, Moo-Keun Song**, Jong-Myoung Lee***, Jeong-Hun Hyun****, Gi-Hun Lee*****, and Jong-Do Kim******,

*Ocean Science and Technology School, Korea Maritime \& Ocean Univ., Busan, 49112, Korea

**Laser Advanced Machining Support Center, Korea Maritime \& Ocean Univ., Busan, 49112, Korea ***IMT Co., Ltd., Suwon, 16675, Korea

****Daewoo Shipbuilding \& Marine Engineering Co., Ltd., Geoje, 53302, Korea

*****Graduate School, Korea Maritime \& Ocean Univ., Busan, 49112, Korea

******Division of Marine System Engineering, Korea Maritime \& Ocean Univ., Busan, 49112, Korea

†Corresponding author: jdkim@kmou.ac.kr

(Received July 13, 2021; Revised August 10, 2021; Accepted August 17, 2021)

\begin{abstract}
In the shipbuilding and marine industry, laser cleaning is considered an eco-friendly technology because it can significantly reduce the generation of secondary waste when removing the paint and oxide layer on a steel surface during ship repair work. Accordingly, various studies are being conducted worldwide for the application of laser cleaning. However, studies on the removal of various types of paint used on ships for anticorrosion and cosmetic effects and on the control of the scanning mode of laser cleaning application parts, such as square and circular, are limited. Therefore, in this study, the effects of the scanning mode and major process parameters were analyzed for four types of specimen coated with different paints and with various thicknesses. Consequently, it was possible to remove the paint on the steel surface completely by using handheld-type laser cleaning equipment with an average power of $100 \mathrm{~W}$. In addition, the working time was reduced and the cleaning performance was improved by determining the scanning mode suitable for the laser cleaning application part and the optimal process parameters for each specimen.
\end{abstract}

Key Words: Laser cleaning process, Hand-held type laser cleaning equipment, Laser scan mode, Anti-corrosive paints for shipbuilding

\section{Introduction}

When the coated paints and oxide layers on the steel surfaces inside and outside the ships are removed during shipbuilding and repairing work of used vessels, a lot of wastes are generated, requiring significant amounts of disposal costs. Furthermore, because there is no ven- tilation system inside vessels, the wastes generated during work often contaminate the surrounding work areas. This causes work delays, reducing work efficiency. Therefore, to resolve the problem caused by conventional technology, it is required to develop laser cleaning technology that can significantly reduce the generation of secondary waste during painting treatment work $^{1-4)}$.

Journal of Welding and Joining, Vol.39 No.5(2021) pp536-541

https://doi.org/10.5781/JWJ.2021.39.5.10 
Because of the benefits of laser cleaning technology, its application areas have been continually increasing, including cultural asset restoration ${ }^{5,6)}$, semiconductors ${ }^{7}$, electric/electronic devices, aircraft ${ }^{8-10)}$, and railway industry ${ }^{11)}$. Particularly in the shipbuilding and marine industry, research has been actively conducted to increase the applicability of laser cleaning technology ${ }^{12-14}$. Through fundamental technology research, our research team has confirmed that laser cleaning technology can be applied to the removal of epoxy paints, shop primers, and oxide layers on steel surfaces in ships ${ }^{1-4)}$. D'Addona et al. removed primers on steel surfaces by adopting laser ablation technology as a pretreatment process of welding for the prevention of weld defects; as a result, they increased the welding efficiency ${ }^{15)}$. It is also important to remove marine microorganisms periodically, which inhabit the surface of ships and offshore structures, to increase ship operational efficiency. Tian et al. reported that they removed the marine microorganisms on the aluminum alloy surface effectively by using nanosecond pulsed fiber laser ${ }^{16)}$. However, there is no previous study has been reported on the cleaning performance according to the thickness of paint surface and various types of anti-corrosive paints that are commonly used in shipyards. Furthermore, there is virtually no study on the scan mode control according to the shape of the laser cleaning-applied part, such as a square and a circle, based on the excellent controllability of the laser.

In this study, therefore, we used the hand-held type laser cleaning equipment that our research team developed to increase the ease of work in narrow areas of the vessel and investigated the cleaning performance improvement for different types of anti-corrosive paints used in shipbuilding. We analyzed the cleaning characteristics according to the scan mode by setting the laser beam's scan mode to the square and circle to increase the ease of work according to the shape of the cleaning-applied part.

\section{Experimental Materials and Method}

In this study, we used the following experimental materials: steel for shipbuilding coated with epoxy and anti-fouling paints used for anti-corrosion in ships; urethane paints used for decorative effects such as color and lusters; and zinc primer paints used for temporary anti-corrosion. Table 1 shows the thickness of the coating, boiling point, and main components for each paint type.

The laser used in the experiment was a Q-switching pulsed fiber laser with an average power of $100 \mathrm{~W}$. Using the low-power laser, we developed air-cooled hand-held laser cleaning equipment and applied it to
Table 1 Properties of experimental materials

\begin{tabular}{|c|c|c|c|}
\hline Property & $\begin{array}{c}\text { Thickness } \\
(\mu \mathrm{m})\end{array}$ & $\begin{array}{c}\text { Boiling } \\
\text { point }\left({ }^{\circ} \mathrm{C}\right)\end{array}$ & $\begin{array}{c}\text { Main } \\
\text { components }\end{array}$ \\
\hline Epoxy & 320 & 220 & $\begin{array}{c}\text { Bisphenol } \\
\text { epoxy A }\end{array}$ \\
\hline $\begin{array}{c}\text { Anti- } \\
\text { fouling }\end{array}$ & 170 & 200 & $\begin{array}{c}\text { Dicopper } \\
\text { oxide }\end{array}$ \\
\hline Urethane & 110 & 260 & $\begin{array}{c}\text { Polyurethane } \\
\text { polymer }\end{array}$ \\
\hline Zn primer & 30 & 907 & Zinc dust \\
\hline
\end{tabular}

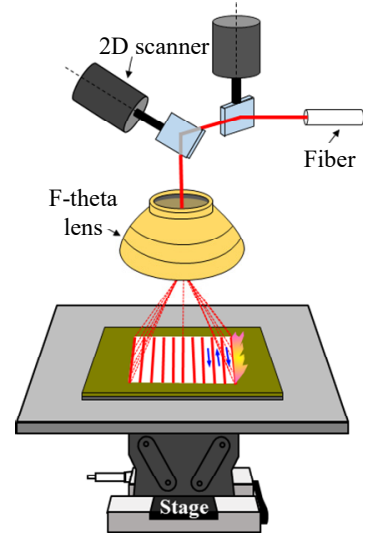

(a) Scan mode : square

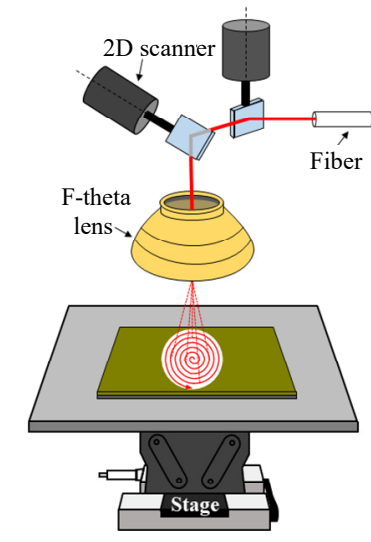

(b) Scan mode : circle
Fig. 1 Schematic diagram of laser cleaning experiment according to scan mode

Table 2 Laser cleaning experimental conditions

\begin{tabular}{|c|c|c|}
\hline Parameters & \multicolumn{2}{|c|}{ Value } \\
\hline Average power, $P_{\text {ave }}$ & \multicolumn{2}{|c|}{$100 \mathrm{~W}$} \\
\hline Energy density, $D_{\mathrm{e}}$ & $9.4 \mathrm{~J} / \mathrm{cm}^{2}$ & $13.6 \mathrm{~J} / \mathrm{cm}^{2}$ \\
\hline Scan speed, $v$ & $5800 \mathrm{~mm} / \mathrm{s}$ & $4800 \mathrm{~mm} / \mathrm{s}$ \\
\hline Scan line overlap rate, $R_{\mathrm{lo}}$ & \multicolumn{2}{|c|}{$20 \%, 50 \%, 70 \%$} \\
\hline Scan mode & \multicolumn{2}{|c|}{ Square, Circle } \\
\hline
\end{tabular}

this study. The laser cleaning experiment was conducted by changing the process parameters such as scan mode, scan line distance, and energy density. Fig. 1 shows the schematic diagram of the experimental method according to the scan mode. Using the 2D scanner inside the laser optical head, the circular laser beam scans square and circular regions. Here, the hand-held laser cleaning equipment's laser head and stage were fixed to obtain quantitative experimental data. When applied on-site, an indicating bar corresponding to the distance from the laser optical head to the focal position was designed to be mounted to maintain the focal length. The scan area was $50 \mathrm{~mm} \times 50 \mathrm{~mm}$ for square areas and $50 \mathrm{~mm}$ in diameter for circular areas. Table 2 shows the laser irradiation conditions according to the main process parameters used in the experiment. 


\section{Experimental Results and Discussion}

\subsection{Coating Removal Characteristics According to Scan Mode}

We conducted an experiment according to the scan mode to increase the ease of work according to the shape of the cleaning-applied part in industrial sites. Fig. 2 shows the scan path diagram of the circular laser beam according to the scan mode and the movement of the laser beam captured by a high-speed camera at certain time intervals. The laser moves repeatedly from top to bottom and from bottom to top when scanning a square area, and draws circles while spiring out from the center when scanning a circular area. Here, overlaps are placed between the laser beams to clean the entire area uniformly.

Fig. 3 shows surface images of the laser-cleaned areas according to the scan mode and the number of scans $\left(N_{\mathrm{s}}\right)$ of the specimen coated with the anti-fouling paint, as the representative of the four experimental material types. The anti-fouling paint that had a thickness of 170 $\mu \mathrm{m}$ was completely removed in five scans. When we examined the coating removal characteristics according to the scan mode, we found that the coating was removed uniformly in the entire area when the laser beam scanned the square area. This was because the laser energy was irradiated uniformly with constant overlaps in the entire area. In contrast, when the circular area was scanned, the thermal energy was concentrated at the center, removing the coating at the center first.

To analyze the damage and thermal effect on the base metal by the laser heat source during laser cleaning, we

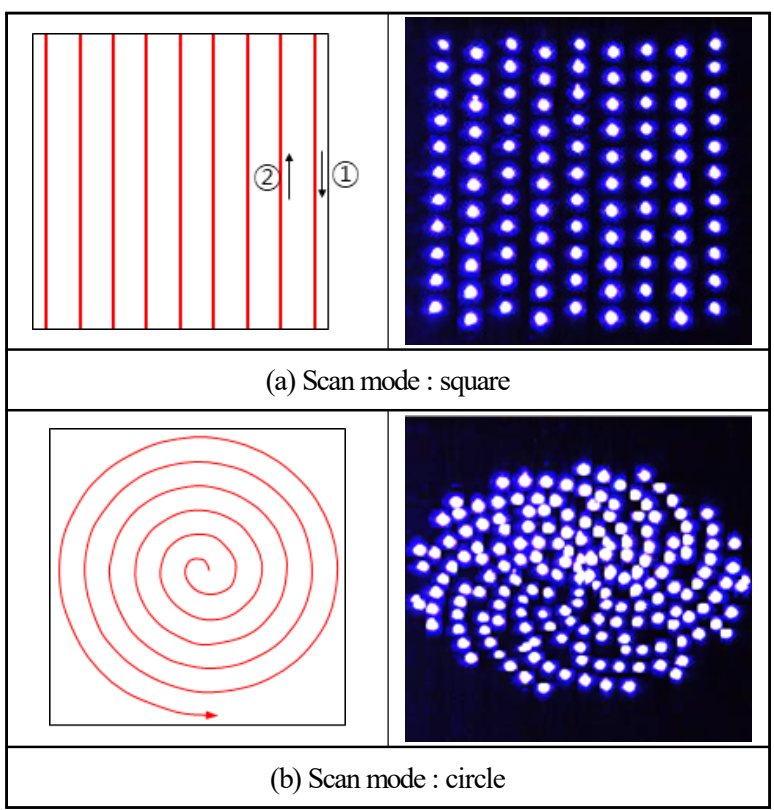

Fig. 2 The scan path of the laser beam according to the scan mode taken by the high-speed camera

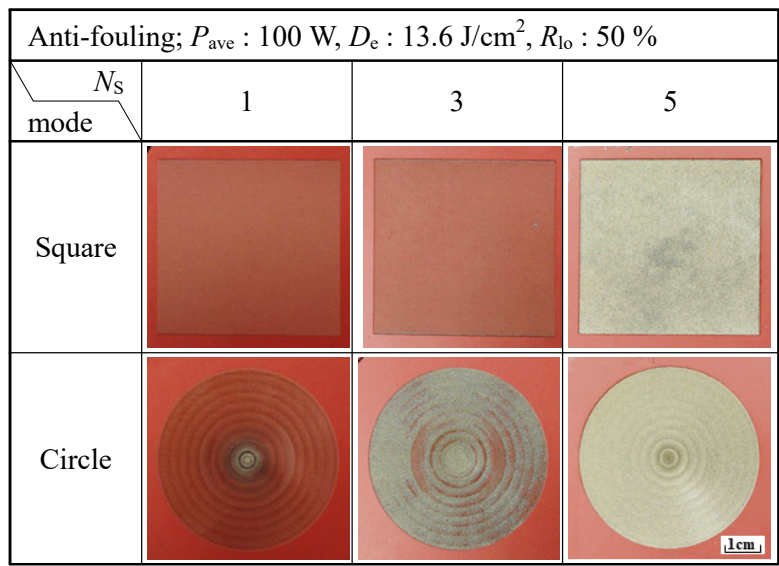

Fig. 3 Laser cleaned surface of the anti-fouling painted specimen according to the scan mode

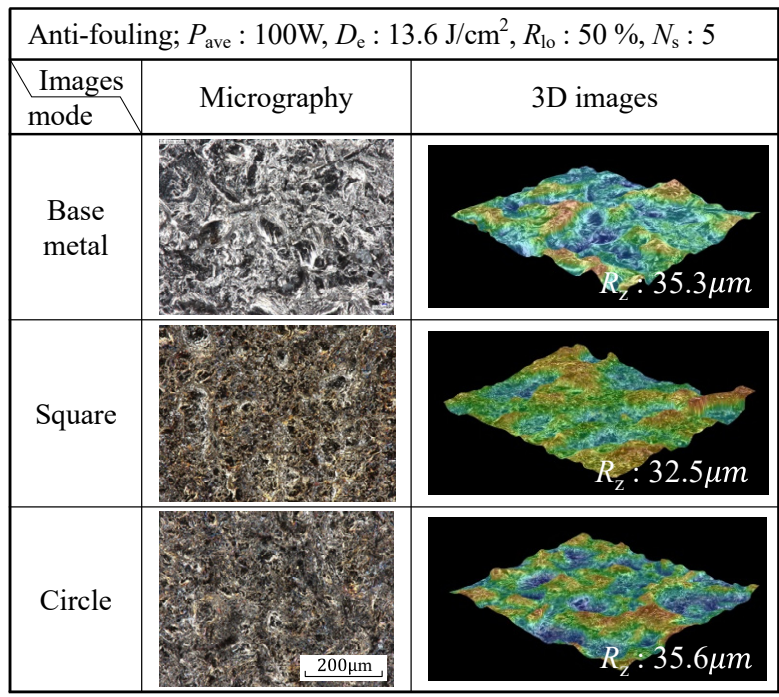

Fig. 4 Micrography and 3D images of base metal and laser cleaned surface when the number of $\operatorname{scans}\left(\mathrm{N}_{\mathrm{s}}\right)$ is 5

magnified and analyzed the surfaces of the base metal and the laser-cleaned specimens. Fig. 4 shows a micrography and its $3 \mathrm{D}$ image for the surfaces at the center position cleaned in square and circular areas under the condition of performing the scan five times. On the base metal, a roughness of about $35 \mu \mathrm{m}$ had been formed to improve the adhesion of the paint, and a silver surface was observed. When the specimens were examined after laser cleaning, we observed the surface shape and roughness value similar to those of the base metal regardless of the scan mode and did not observe the thermal effects such as oxidation and discoloration.

Hence, we observed excellent cleaning performance without mechanical and thermal damages of the base metal when scanning not only the square area but also the circular area where the energy was concentrated at the center. Since the laser cleaning technology enables selective cleaning of target materials, which was not possible with traditional mechanical/chemical cleaning 
technology, we expect that significant improvements will be achieved in terms of product quality and work time.

\subsection{Effect of Scan Line Overlap Rate}

The scan line overlap rate is determined by the scan line distance, which is the distance between two lines, as shown in the schematic diagram in Fig. 5. In this study, we changed the scan line overlap rate to $20 \%$, $50 \%$, and $70 \%$.

Fig. 6 shows the paint removal conditions for the four paint types according to the scan line overlap rate. In the case of epoxy paint, the removal was successful when the laser scanning was performed 10 times at an overlap rate condition of $20 \%, 7$ times at a condition of $50 \%$, and 5 times at a condition of $70 \%$. In other words, as the scan line overlap rate increased, the paint removal condition decreased. The same trend was observed in other specimens as well. When the scan line overlap rate increased from $20 \%$ to $70 \%$, the paint removal condition decreased from 7 times to 3 times in the case of the anti-fouling paint; from 3 times to 2 times in the case of the urethane paint; and 4 times to once in the case of the zinc primer paint. This is because as the line overlap rate increases, the number of laser lines irradiated on a scan area of $50 \mathrm{~mm} \times 50 \mathrm{~mm}$ increases, which increases the thickness of the paint re-

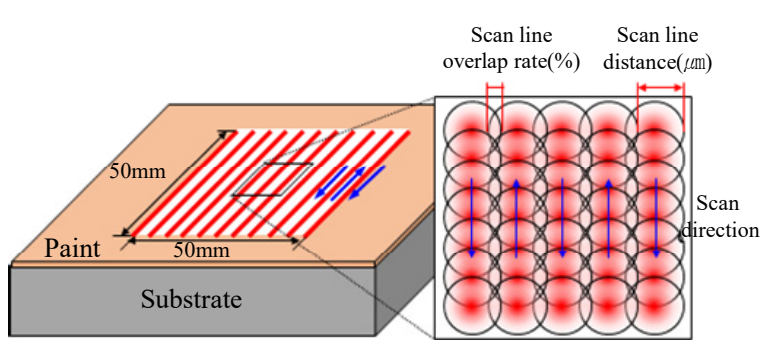

Fig. 5 Schematic diagram of laser cleaning experimental method according to scan line overlap rate

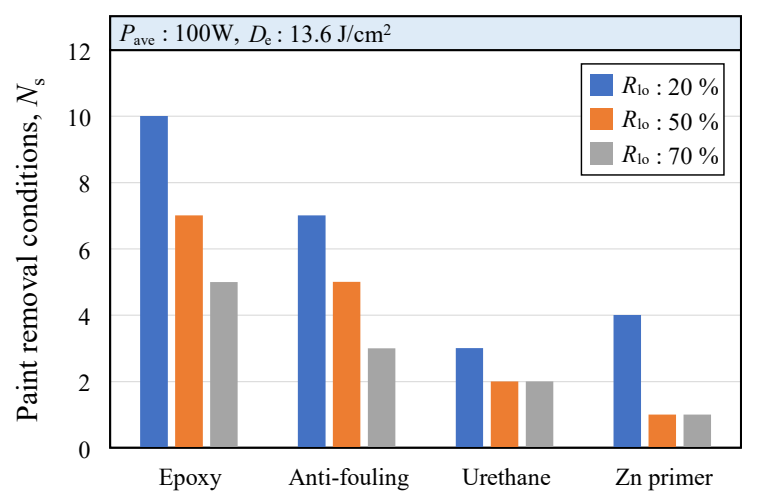

Fig. 6 Paint removal conditions according to the line overlap rate for each specimen moved with one laser scan due to the heat build-up in the material. Furthermore, through the fundamental research, our research team has confirmed that uniform cleaning is difficult under the condition of a low overlap rate because the transfer of thermal energy is insufficient in the edge areas due to the laser beam characteristics of Gaussian distribution ${ }^{1,2)}$. Therefore, we determined that an overlap condition of $20 \%$ is not suitable when cleaning paints.

As the overlap rate increases, the number of scans for the paint removal decreases, but the scan time increases. Therefore, we need to consider the total work time calculated by using the time per scan and the number of scans. Under an energy density condition of $13.6 \mathrm{~J} / \mathrm{cm}^{2}$, the time per scan is $7.96 \mathrm{~s}$ when the overlap rate is $50 \%$, and it increases by twice to $13.25 \mathrm{~s}$ when the overlap rate increases to $70 \%$. In short, when the total work time was compared, we found that the work time was shortened significantly under an overlap rate condition of $50 \%$ compared to a condition of $70 \%$, confirming that efficient work is feasible. Based on this, we have found that selection of the optimal overlap rate is important because if the overlap rate increases more than necessary, it will increase the work time and can have a thermal impact on the base metal.

\subsection{Effect of Energy Density}

The experimental results according to the scan line overlap rate showed that in the case of the urethane and zinc primer paints, there was no difference in the number of scans when the scan line overlap rate increased from $50 \%$ to $70 \%$. Therefore, we conducted an additional experiment by reducing the energy density to reduce the work time for these specimens. As the energy density decreased, the scanning speed increased, reducing the time per scan. Here, the energy density is defined as the pulsed energy irradiated per unit area.

Fig. 7 shows the removal conditions of the urethane

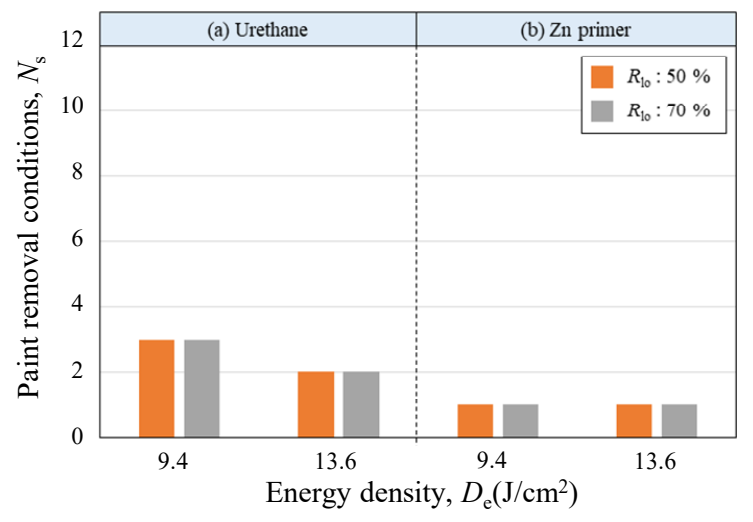

Fig. 7 Paint removal conditions according to the energy density for each specimen 


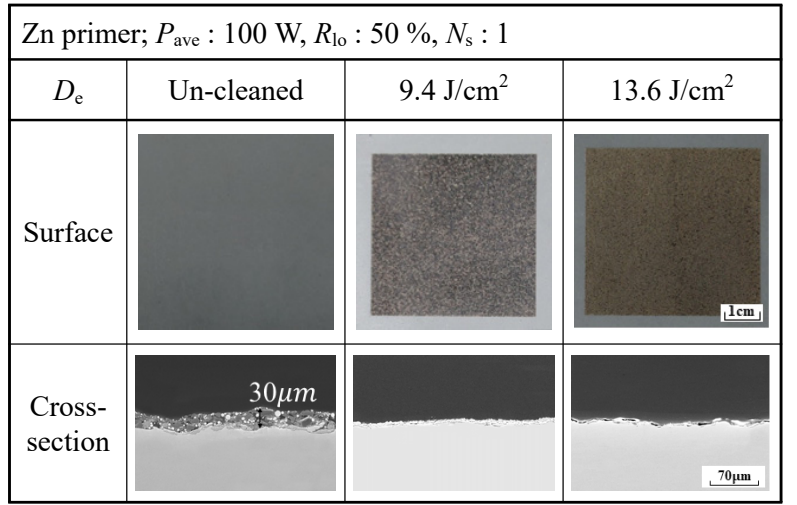

Fig. 8 Laser cleaned surfaces of shop primer painted steel with energy density

and zinc primer paints according to the energy density at scan line overlap conditions of $50 \%$ and $70 \%$, respectively. In the case of the urethane paint, the number of scans for the paint removal decreased when the energy density increased. However, the zinc primer paint was removed through one laser scan, even when the energy density changed. In the case of the energy density increasing from $9.4 \mathrm{~J} / \mathrm{cm}^{2}$ to $13.6 \mathrm{~J} / \mathrm{cm}^{2}$, the time per scan is $5.46 \mathrm{~s}$ and $7.96 \mathrm{~s}$, respectively, when the overlap rate is $50 \% ; 8.2 \mathrm{~s}$ and $13.25 \mathrm{~s}$, respectively, when the overlap rate is $70 \%$. When the total work time was compared for each process parameter, we found that the conditions for the most efficient removal of each paint film were: an overlap rate of $50 \%$ and an energy density of $13.6 \mathrm{~J} / \mathrm{cm}^{2}$ for the urethane paint; an overlap rate of $50 \%$ and an energy density of $9.4 \mathrm{~J} / \mathrm{cm}^{2}$ for the zinc primer paint.

Fig. 8 shows surface and cross-sectional images of the laser-cleaned surface of the specimens coated with the zinc primer according to the energy density. We can observe that the zinc primer paint was removed in just one laser scan in every condition. The XRD component analysis results of the cleaned surfaces shown in Fig. 9 also confirm that the peak of $\mathrm{Zn}$, the main component of the zinc primer paint, is not detected.

In sum, the work time can be reduced when removing a thick paint film such as urethane by increasing the amount removed per scan at a high energy density, which decreases the number of scans. On the other hand, in the case of thin paint film such as zinc primer paint, the energy density has no significant effect because the paint is removed in just one laser scan. Therefore, by selecting the minimal threshold conditions of removing paints, cleaning work can be performed efficiently.

\section{Conclusions}

In this study, we used the developed hand-held laser

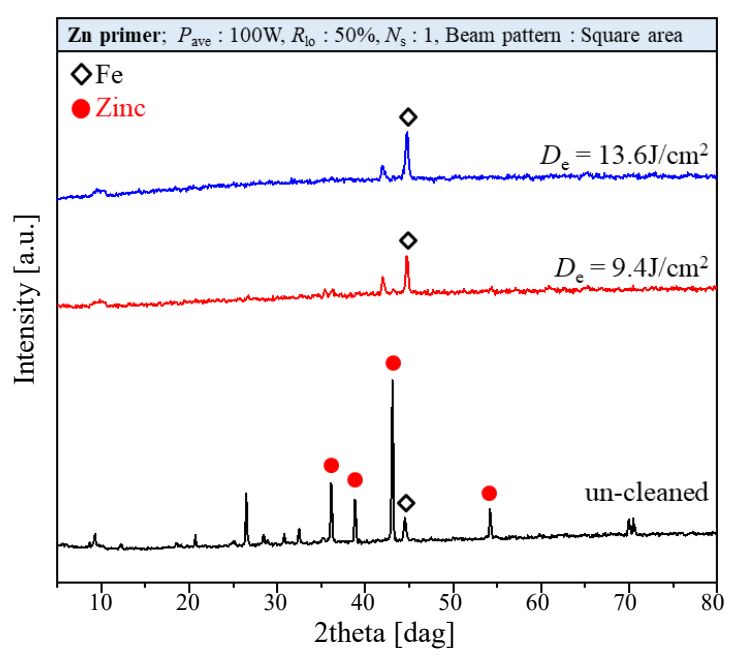

Fig. 9 XRD results of laser cleaned surfaces by energy density

cleaning equipment and analyzed the effects of major cleaning process parameters including the scan modes of square and circle for four types of specimens coated with different paints and thicknesses. As a result, we reached the following conclusions.

1) Using a circular laser beam, square and circular areas were completely cleaned, and we observed excellent cleaning performance without mechanical and thermal damages of the base metal caused by the laser heat source. In the cleaning process, the paint was uniformly removed when a square area was scanned, and the paint at the center was removed first when a circular area was scanned.

2) According to the results of analyzing the effects of the scan line overlap rate, the cleaning work can be finished at the earliest time when the overlap rate is $50 \%$. Based on this, we have found that selection of the optimal overlap rate is important because if the overlap rate increases more than necessary, it will increase the work time and can have a thermal impact on the base metal.

3) Efficient cleaning work was possible at a condition of a high energy density for the removal of a thick paint such as urethane and at a condition of relatively low energy density for the removal of a thin paint such as zinc primer. The optimal cleaning conditions for each paint type were as follows: a scan line overlap rate of $50 \%$ and an energy density of $13.6 \mathrm{~J} / \mathrm{cm}^{2}$ in the case of the epoxy, anti-fouling, and urethan specimens; a scan line overlap rate of $50 \%$ and an energy density of $9.4 \mathrm{~J} / \mathrm{cm}^{2}$ in the case of the zinc primer specimens.

4) In sum, by using the hand-held cleaning equipment with the average power of $100 \mathrm{~W}$, we completely removed different anti-corrosion paints on the steel surfa- 
ces for shipbuilding. Furthermore, the cleaning performance can be improved and the work time can be shortened compared to conventional technology by deriving the optimal process parameters according to the paint type, the thickness of the paint, and the scan mode suitable for the shape of the laser cleaning-applied surface.

\section{Acknowledgment}

This work was supported by the Korea Institute for Advancement of Technology (KIAT) grant funded by the Korea Government (MOTIE) (P0008763, The Competency Development Program for Industry Specialist).

ORCID: Ji-Eon Kim: http://orcid.org/0000-0003-0445-5638 ORCID: Moo-Keun Song: http://orcid.org/0000-0001-6799-1302 ORCID: Jong-Myoung Lee: http://orcid.org/0000-0001-8638-5826 ORCID: Jeong-Hun Hyun: http://orcid.org/0000-0002-2643-8284 ORCID: Jong-Do Kim: http://orcid.org/0000-0002-2125-0426

\section{References}

1. J. E. Kim, M. K. Song, J. M. Lee, J. H. Hyun, and J. D. Kim, A Study on the Effect of Overlap Rate on Laser Beam Cleaning Characteristics while Cleaning Paint Using a Low Power Pulsed Laser( I ), J. Weld. Join. 37(5) (2019) 435-440.

https://doi.org/10.5781/JWJ.2019.37.5.1

2. J. E. Kim, M. K. Song, J. M. Lee, J. H. Hyun, and J. D. Kim, A Study on the Effect of Overlap Rate on Laser Beam Cleaning Characteristics while Cleaning Paint Using a Low Power Pulsed Laser( П), J. Weld. Join. 37(5) (2019) 441-447.

https://doi.org/10.5781/JWJ.2019.37.5.2

3. J. E. Kim, M. S. Han, and J. D. Kim, Removal characteristics of shop-primer paint by laser energy density in Q-switching fiber laser cleaning, Modern Phys. Lett. B, 34(7) (2020) 2040042.

https://doi.org/10.1142/S0217984920400424

4. J. E. Kim, M. K. Song, M. S. Han, and J. D. Kim, A study on the application of laser cleaning process in shipbuilding industries using $100 \mathrm{~W}$ fiber laser, J. Mech. Sci. Technol. 35(4) (2021) 1421-1427. https://doi.org/10.1142/S0217979221400063

5. O. A. Kareem and M. A. Harith, Evaluating the use of laser radiation in cleaning of copper embroidery threads on archaeological Egyptian textiles, Appl. Surf. Sci. 254 (18) (2008) 5854-5860. https://doi.org/10.1016/j.apsusc.2008.03.144
6. Y. Koh and I. Sarady, Cleaning of corroded iron artefacts using pulsed TEA $\mathrm{CO}_{2}$ and Nd:YAG-lasers, $J$. Cultural Heritage, 4(1) (2003) 129-133. https://doi.org/10.1016/S1296-2074(02)01140-8

7. J. Graf, B. S. Luk'yanchuk, M. Mosbacher, M. H. Hong, C. T. Chong, J. Boneberg, and P. Leiderer, Matrix laser cleaning: a new technique for the removal of nanometer sized particles from semiconductors, Appl. Phys. a-Mater. Sci. Process. 88(2) (2007) 227-230. https://doi.org/10.1007/s00339-007-4017-6

8. M.W. Turner, P. L. Crouse, L. Li, and A. J. E. Smith, Investigation into $\mathrm{CO}_{2}$ laser cleaning of titanium alloys for gas-turbine component manufacture, Appl. Surf. Sci. 252 (2006) 4798-4802. https://doi.org/10.1016/j.apsusc.2005.06.061

9. G. Zhu, S. Wang, W. Cheng, Y. Ren, and D. Wen, Corrosion and wear performance of aircraft skin after laser cleaning, Opt. Laser Technol. 132 (2020) 106475. https://doi.org/10.1016/j.optlastec.2020.106475

10. Q. H. Tang, D. Zhou, Y. L. Wang, and G. F. Liu, Laser cleaning of sulfide scale on compressor impeller blade, Appl. Surf. Sci. 355 (2015) 334-340. https://doi.org/10.1016/j.apsusc.2015.07.128

11. Z. Kuang, W. Guo, J. Li, Y. Jin, D. Qian, J. Ouyang, L. Fu, E. Fearon, R. Hardacre, Z. Liu, and L. Li, Nanosecond fibre laser paint stripping with suppression of flames and sparks, J. Mater. Process. Tech. 266 (2019) 474-483. https://doi.org/10.1016/j.jmatprotec.2018.11.028

12. Md. Shamsujjoha, S. R. Agnew, M. A. Melia, J. R. Brooks, T. J. Tyler, and J. M. Fitz-Gerald, Effects of laser ablation coating removal (LACR) on a steel substrate: Part 1, Surf. Coat. Technol. 281 (2015) 193-205. https://doi.org/10.1016/j.surfcoat.2015.01.071

13. Md. Shamsujjoha, S. R. Agnew, J. R. Brooks, T. J. Tyler, and J. M. Fitz-Gerald, Effects of laser ablation coating removal (LACR) on a steel substrate: Part 2, Surf. Coat. Technol. 281 (2015) 206-214. https://doi.org/10.1016/j.surfcoat.2015.02.034

14. G. X. Chen, T. J. Kwee, K. P. Tan, Y. S. Choo, and M. H. Hong, High-Power Fibre Laser Cleaning for Green Shipbuilding, J. Laser Micro/Nanoeng. 7(3) (2012) 249-253. https://doi.org/10.2961/JLMN.2012.03.0003

15. D. M. D'Addona, S. Genna, A. Giordano, C. Leone, D. Matarazzo, and L. Nele, Laser Ablation of Primer During the Welding Process of Iron Plate for Shipbuilding Industry, Procedia CIRP, 33 (2015) 464-469. https://doi.org/10.1016/j.procir.2015.06.055

16. Z. Tian, Z. Lei, X. Chen, and Y. Chen, Evaluation of laser cleaning for defouling of marine biofilm contamination on aluminum alloys, Appl. Surf. Sci. 499 (2020) 144060 .

https://doi.org/10.1016/j.apsusc.2019.144060 


\section{휴대용 레이저 클리닝 장비를 이용한 서로 다른 조선용 방청도료의 클리닝 성능 향상을 위한 실험적 연구}

\section{Experimental Investigations Into Improvement of Cleaning Performance for Anti-Corrosive Paints for Shipbuilding using Hand-Held Type Laser Cleaning Equipment}

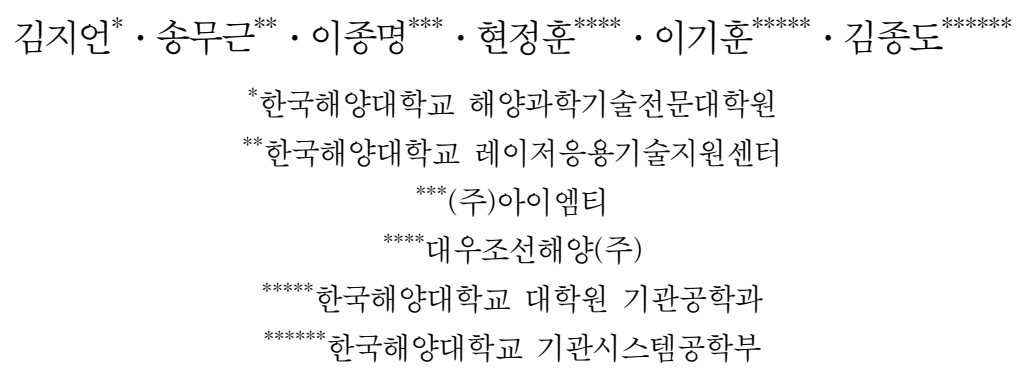

1. 서 론

신조선과 중고선의 리페어링 작업시 선박 내·외부에 도장된 페인트 및 강재 표면의 산화층을 제거하는 것은 많은 폐기물을 발생시키며 처리비용 또한 상당하다. 특 히 선박 내부에는 환기시스템이 갖추어지지 않아서 작 업시 발생되는 폐기물에 의해 주변 작업영역까지 오염 되는 경우가 발생한다. 이는 작업시간 지연을 유발하여 작업 효율을 저하시킨다. 따라서 기존의 기술로 인한 문제점을 해결하기 위하여 도장처리 작업시 2 차 폐기 물의 발생을 현저하게 감소시킬 수 있는 레이저 클리닝 기술 개발이 요구된다 ${ }^{1-4)}$

레이저 클리닝 기술의 이점으로 인하여 문화재 복원 ${ }^{5,6)}$, 반도체 ${ }^{7)}$, 전기·전자, 항공기 ${ }^{8-10)}$, 철도 산업 ${ }^{11)}$ 등 그 적용분야는 나날이 증가하고 있다. 특히 조선해양분 야에서는 레이저 클리닝 기술의 적용성을 높이기 위한 연구가 최근 활발하게 진행되고 있다 ${ }^{12-14)}$. 우리 연구 진들은 기초 기술 연구를 통하여 선박용 강재 표면의 에폭시 페인트, 숍프라이머 및 산화층의 제거에 레이저 클 리닝 기술의 적용 가능성을 확인하였다 ${ }^{1-4)}$. D'Addona 등 은 용접부 결함을 방지하기 위하여 용접 전처리 공정으 로 레이저 어블레이션 기술을 도입하여 강재 표면의 프 라이머를 제거함으로써 용접 효율을 보다 높일 수 있었 다 ${ }^{15)}$. 또한 운항효율을 높이기 위해서는 선박 및 해상 구조물 표면에 서식하는 해양 미생물을 주기적으로 제 거하는 것이 매우 중요하다. Tian 등은 나노초 펄스
파이버 레이저를 사용하여 알루미늄합금 표면의 해양 미생물을 효과적으로 제거하였음을 보고하였다 ${ }^{16)}$. 하지 만 조선소에서 보편적으로 사용되는 다양한 종류의 방 청 도료 및 도장면 두께에 따른 클리닝 성능에 관한 선 행연구 결과는 보고되지 않았다. 또한 레이저의 우수한 제어성을 활용한 사각형 및 원형과 같은 레이저 클리닝 적용부 형상에 따른 스캔 모드 제어에 관한 연구는 전 무한 실정이다.

따라서 본 논문에서는 선박의 협소구역에서의 작업 용이성을 높이기 위하여 우리 연구진들이 개발한 휴대 용 레이저 클리닝 장비를 활용하여, 서로 다른 조선용 방청 도료의 클리닝 성능 향상을 위한 연구를 진행하였 다. 특히, 클리닝 적용부의 형상에 따른 작업의 용이성을 높이기 위하여 레이저 빔의 스캔 모드를 사각형 및 원 형으로 하여, 스캔 모드에 따른 클리닝 특성 분석하였다.

\section{2. 실험 재료 및 방법}

본 연구에서는 선박에서 방식을 위해 사용되는 에폭 시 및 방오 도료, 색상 및 광택 등의 미장효과를 위해 사용되는 우레탄 도료 및 강재의 적재시 임시방청을 위 해 사용되는 아연 프라이머 도료로 도장된 조선용 강재 를 실험재료로 사용하였다. 도료별 도장면의 두께와 증 발점 및 주요 성분을 Table 1 에 나타내었다.

실험에 사용된 레이저는 평균 출력 $100 \mathrm{~W}$ Q-스위칭 펄스 파이버 레이저이다. 이와 같은 저출력 레이저를 사용하여 공랭식의 휴대용 레이저 클리닝 장비를 개발 하여 본 연구에 적용하였다. 레이저 클리닝 실험은 스 
Table 1 Properties of experimental materials

\begin{tabular}{|c|c|c|c|}
\hline Property & $\begin{array}{c}\text { Thickness } \\
(\mu \mathrm{m})\end{array}$ & $\begin{array}{c}\text { Boiling } \\
\text { point }\left({ }^{\circ} \mathrm{C}\right)\end{array}$ & $\begin{array}{c}\text { Main } \\
\text { components }\end{array}$ \\
\hline Epoxy & 320 & 220 & $\begin{array}{c}\text { Bisphenol } \\
\text { epoxy A }\end{array}$ \\
\hline $\begin{array}{c}\text { Anti- } \\
\text { fouling }\end{array}$ & 170 & 200 & $\begin{array}{c}\text { Dicopper } \\
\text { oxide }\end{array}$ \\
\hline Urethane & 110 & 260 & $\begin{array}{c}\text { Polyurethane } \\
\text { polymer }\end{array}$ \\
\hline Zn primer & 30 & 907 & Zinc dust \\
\hline
\end{tabular}

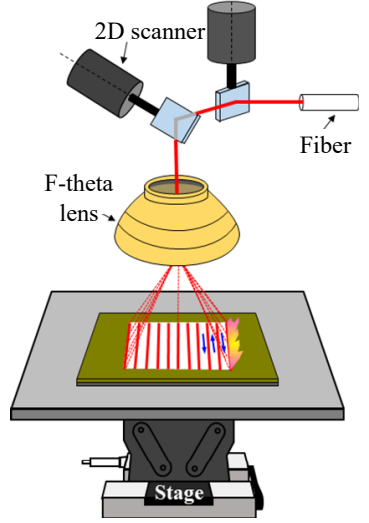

(a) Scan mode : square

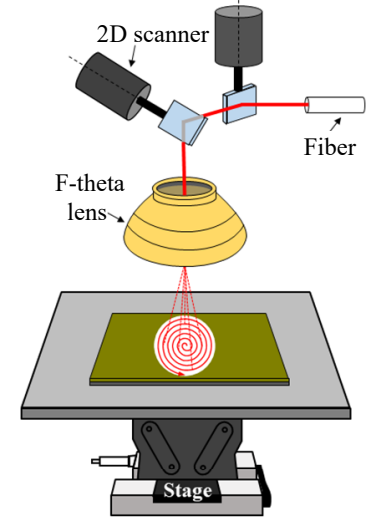

(b) Scan mode : circle
Fig. 1 Schematic diagram of laser cleaning experiment according to scan mode

Table 2 Laser cleaning experimental conditions

\begin{tabular}{|c|c|c|}
\hline Parameters & \multicolumn{2}{|c|}{ Value } \\
\hline Average power, $P_{\text {ave }}$ & \multicolumn{2}{|c|}{$100 \mathrm{~W}$} \\
\hline Energy density, $D_{\mathrm{e}}$ & $9.4 \mathrm{~J} / \mathrm{cm}^{2}$ & $13.6 \mathrm{~J} / \mathrm{cm}^{2}$ \\
\hline Scan speed, $v$ & $5800 \mathrm{~mm} / \mathrm{s}$ & $4800 \mathrm{~mm} / \mathrm{s}$ \\
\hline Scan line overlap rate, $R_{\mathrm{lo}}$ & \multicolumn{2}{|c|}{$20 \%, 50 \%, 70 \%$} \\
\hline Scan mode & \multicolumn{3}{|c|}{ Square, Circle } \\
\hline
\end{tabular}

캔 모드, 스캔 라인 간격 및 에너지 밀도와 같은 공정 변수를 변화시키면서 진행되었다. 스캔 모드에 따른 실 험방법 모식도는 Fig. 1에 나타내었다. 레이저 광학헤 드 내부의 $2 \mathrm{D}-$ 스캐너에 의해 원형의 레이저빔이 사각 형 및 원형 영역을 스캔한다. 이때, 정량적인 실험 데 이터를 얻기 위하여 휴대용 레이저 클리닝 장비의 레이 저 헤드와 스테이지는 고정하였다. 현장 적용시에는 집 광 헤드로부터 초점까지의 거리에 대응하는 지시바 (indicating bar)를 장착하여 초점거리를 유지하도록 설계하였다. 스캔면적은 사각형 영역의 경우 $50 \mathrm{~mm} \times$ $50 \mathrm{~mm}$ 이며, 원형 영역의 경우 직경 $50 \mathrm{~mm}$ 이다. 실 험에 사용된 주된 공정변수에 따른 레이저 조사 조건은 Table 2에 나타내었다.

\section{3. 실험 결과 및 고찰}

\section{1 스캔 모드에 따른 도막 제거 특성}

산업현장에서 클리닝 적용부의 형상에 따른 작업의 용이성을 높이기 위하여 스캔 모드에 따른 실험을 진행 하였다. Fig. 2는 스캔 모드에 따른 원형 레이저빔의 스캔경로 모식도와 고속도 카메라로 촬영된 실제 레이 저빔의 이동을 일정한 시간 간격으로 합성하여 나타낸 것이다. 레이저빔은 사각형 영역을 스캔할 때에 위에서 아래로, 아래에서 위로 움직임을 반복하며, 원형 영역 을 스캔할 경우 중심에서 나선형으로 뻗어나가며 원을 그린다. 이때, 레이저빔 간에 중첩을 주어 전체 면적을 균일하게 클리닝 할 수 있도록 하였다.

Fig. 3은 4종류의 실험재료 중 대표적으로 방오 도 료로 도장된 시험편의 스캔 모드 및 스캔횟수 $\left(N_{\mathrm{S}}\right)$ 에 따른 레이저 클리닝부의 표면 사진을 나타낸다. 두께 $170 \mu \mathrm{m}$ 의 방오도료 도막은 스캔횟수 5 회에 완전하게 제거되었다. 스캔 모드에 따른 도막 제거 특성을 살펴 보면, 레이저빔이 사각형 영역을 스캔할 때, 도막이 전 체적으로 균일하게 제거되었다. 이는 전체 면적에서 일 정한 중첩을 가지며 균일하게 레이저 에너지가 조사되 기 때문이다. 이에 반해 원형 영역을 스캔할 경우 중심 부에서 레이저 열에너지가 집중되어 중심부의 도막이 우선적으로 제거되는 것을 확인할 수 있다.

레이저 클리닝시 레이저 열원에 의한 모재의 손상 및 열적 영향을 분석하기 위하여 모재와 레이저 클리닝된 시험편의 표면을 확대하여 분석하였다. Fig. 4 는 모재

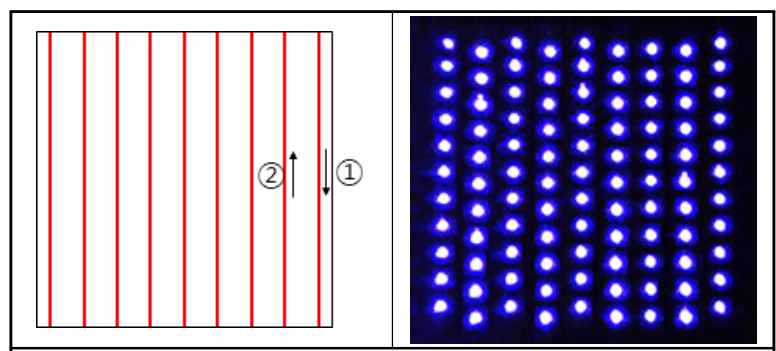

(a) Scan mode : square

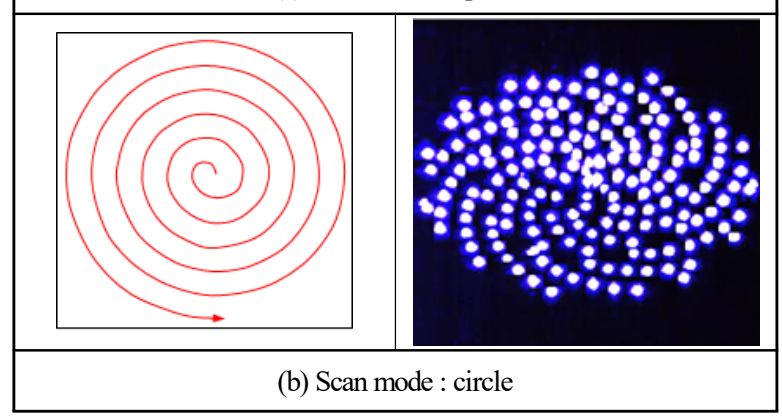

Fig. 2 The scan path of the laser beam according to the scan mode taken by the high-speed camera 


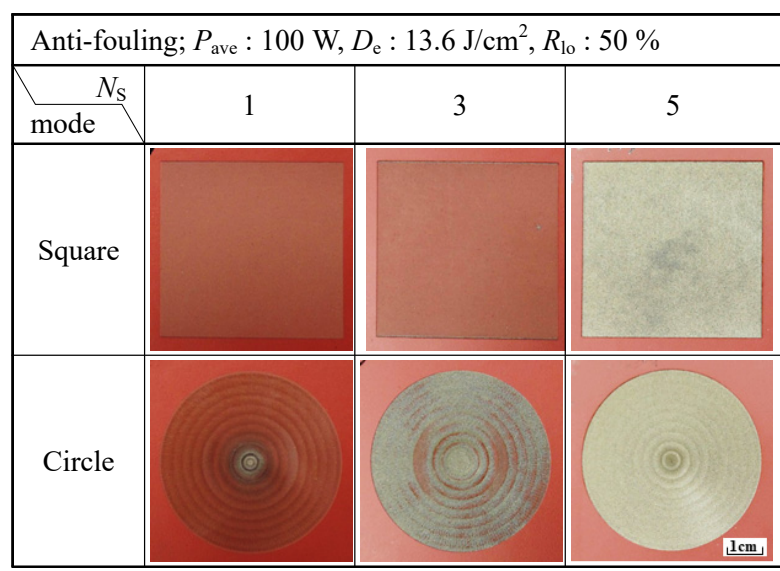

Fig. 3 Laser cleaned surface of the anti-fouling painted specimen according to the scan mode

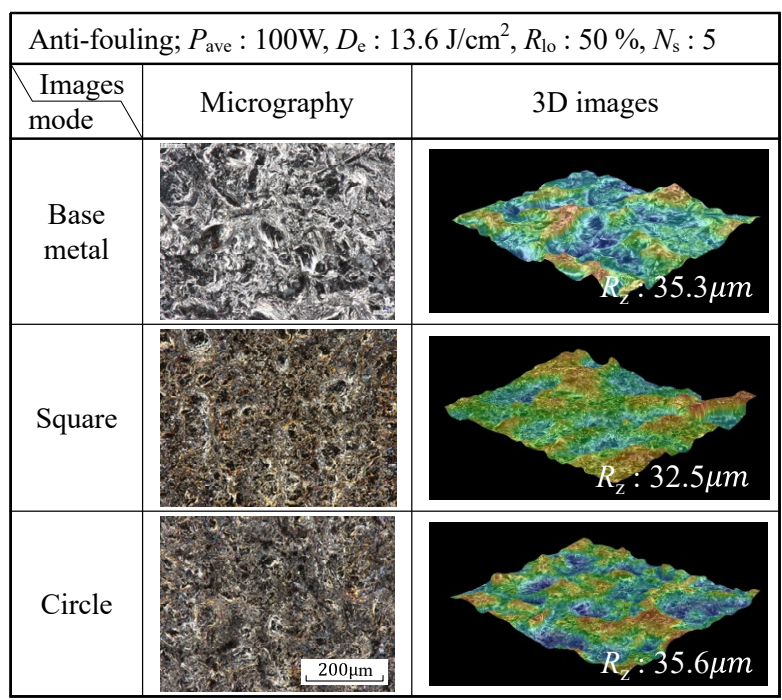

Fig. 4 Micrography and 3D images of base metal and laser cleaned surface when the number of scans $\left(\mathrm{N}_{\mathrm{s}}\right)$ is 5

와 스캔횟수 5 회의 조건에서 사각형과 원형 영역으로 클리닝된 시험편의 중심부 표면 확대 사진과 이를 $3 \mathrm{D}$ 이미지화한 것을 보여준다. 모재는 페인트의 접착력 향 상을 위하여 약 $35 \mu \mathrm{m}$ 의 조도가 형성되어있으며, 은색 빛의 표면이 관찰된다. 레이저 클리닝 후 시험편을 살 펴보면, 스캔 모드에 관계 없이 모재와 유사한 표면 형 상과 조도값이 관찰되며 산화 및 변색 등의 열적 영향 은 관찰되지 않았다.

따라서 사각형 영역을 스캔할 때는 물론이며, 중앙부 에서 에너지가 집중되는 원형 영역을 스캔할 경우에도 모재의 기계적 및 열적 손상이 없는 우수한 클리닝 성 능을 관찰할 수 있었다. 이는 레이저 클리닝 기술을 통 하여 기존의 기계적 · 화학적 클리닝 기술로는 불가능하 였던 타겟 물질의 선택적 클리닝이 가능해짐으로써 제 품의 품질과 작업시간 측면에서 상당한 개선을 이루어 낼 수 있을 것으로 판단된다.

\section{2 스캔 라인 중첩률의 영향}

스캔 라인 중첩률은 Fig. 5에 나타낸 모식도와 같이 라인과 라인사이의 거리인 스캔 라인간격에 의해서 결 정된다. 본 연구에서는 스캔 라인 중첩률을 $20 \%, 50 \%$ 및 $70 \%$ 로 변화시켰다.

Fig. 6은 에너지 밀도 $13.6 \mathrm{~J} / \mathrm{cm}^{2}$ 의 조건에서 스캔 라인 중첩률에 따른 서로 다른 4 종류의 도막 제거조건 을 나타낸다. 에폭시 도막의 경우 중첩률 $20 \%$ 조건에 서 10 회, $50 \%$ 조건에서 7 회, $70 \%$ 조건에서 5 회의 레이저 스캔 후에 제거되었다. 즉, 스캔 라인 중첩률이 증가할수록 도장면 제거 조건이 감소하였다. 이러한 경 향은 다른 시험편에서도 동일하게 관찰되었다. 스캔 라 인 중첩률이 $20 \%$ 에서 $70 \%$ 로 증가하였을 때, 도장면 제거 조건은 방오도료 도막의 경우 7회에서 3회로, 우 레탄 도막의 경우 3 회에서 2 회로, 아연 프라이머 도막 의 경우 4 회에서 1 회로 감소하였다. 이는 라인 중첩률 이 증가할수록 $50 \mathrm{~mm} \times 50 \mathrm{~mm}$ 의 스캔 영역에 조사되 는 레이저 라인의 수가 증가하여, 재료로의 열 축적에 의해 1 회 레이저 스캔시 제거되는 도막의 두께가 증가 하기 때문이다. 또한 앞선 우리 연구진들의 기초 연구 를 통하여, 가우시안 분포의 레이저빔 특성상 가장자리 영역에서 열에너지의 전달이 충분하지 않기 때문에 중 첩률이 낮은 조건에서는 균일한 클리닝이 어려운 것을

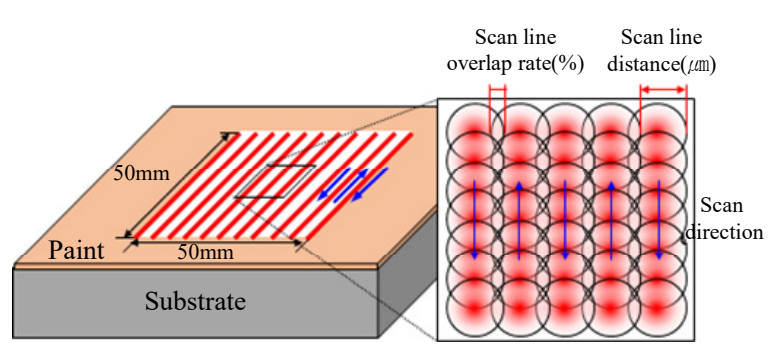

Fig. 5 Schematic diagram of laser cleaning experimental method according to scan line overlap rate

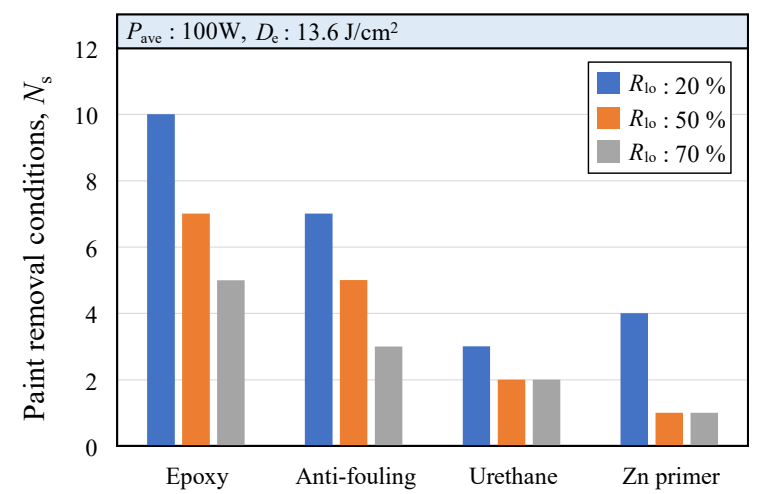

Fig. 6 Paint removal conditions according to the line overlap rate for each specimen 
확인할 수 있었다 ${ }^{1,2)}$. 따라서 중첩률 $20 \%$ 조건은 도막 의 클리닝시 적합하지 않은 조건으로 판단하였다.

중첩률이 증가할수록 도장면 제거를 위한 스캔 횟수 는 감소하지만, 스캔 시간은 증가하게 된다. 따라서 1 회 스캔 시간과 스캔 횟수를 계산한 총 작업시간을 고 려해 볼 필요가 있다. 에너지 밀도 $13.6 \mathrm{~J} / \mathrm{cm}^{2}$ 의 조건 에서 중첩률이 $50 \%$ 인 경우 1회 스캔 시간은 $7.96 \mathrm{~s}$ 이며, 중첩률이 $70 \%$ 로 증가하게 되면 스캔 시간은 약 2 배 증가하여 $13.25 \mathrm{~s}$ 가 된다. 결과적으로 총 작업시 간을 비교하였을 때, 중첩률 $50 \%$ 조건에서 $70 \%$ 조 건 대비 작업시간을 대폭 단축시킴으로써 효율적인 작 업이 가능함을 확인하였다. 이를 통하여 필요 이상의 중첩률 증가는 작업시간의 증대를 야기하고, 모재에 열 적영향을 미칠 수 있으므로 최적의 중첩률 선정이 중요 함을 알 수 있다.

\section{3 에너지 밀도의 영향}

스캔 라인 중첩률에 따른 실험 결과, 우레탄 및 아연 프라이머 도막은 스캔 라인 중첩률이 $50 \%$ 에서 $70 \%$ 로 증가하여도 스캔횟수에 차이가 나지 않았다. 따라서 해당 시험편에 대하여 작업시간을 보다 단축시키고자 에너지 밀도를 낮추어 추가적인 실험을 진행하였다. 에 너지 밀도가 감소할수록 스캔 속도가 증가하여 1회 스 캔시간을 줄일 수 있다. 이때, 에너지 밀도는 단위 면 적당 조사된 펄스 에너지로 정의된다.

Fig. 7은 스캔 라인 중첩률 $50 \%, 70 \%$ 조건에서 에너지 밀도에 따른 우레탄 및 아연 프라이머 도막의 제거 조건을 나타낸다. 우레탄 도막의 경우 에너지 밀 도가 증가하면 도막 제거를 위한 스캔횟수가 감소하였 으나, 아연 프라이머 도막의 경우 에너지 밀도의 변화 에도 1 회의 레이저 스캔을 통해 제거되었다. 1 회 스캔 시간은 에너지 밀도가 $9.4 \mathrm{~J} / \mathrm{cm}^{2}$ 에서 $13.6 \mathrm{~J} / \mathrm{cm}^{2}$ 로

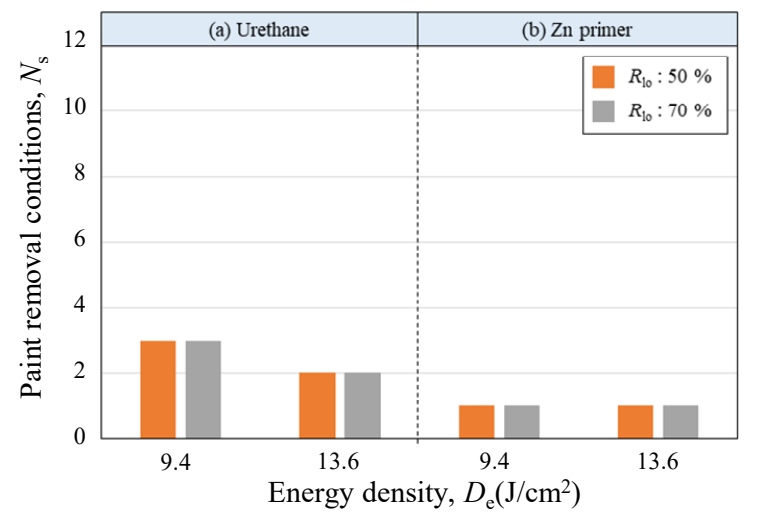

Fig. 7 Paint removal conditions according to the energy density for each specimen
증가할 때, 중첩률이 $50 \%$ 인 경우 각각 $5.46 \mathrm{~s}$ 및 $7.96 \mathrm{~s}$ 이며, 중첩률이 $70 \%$ 인 경우 각각 $8.2 \mathrm{~s}$ 및 $13.25 \mathrm{~s}$ 이다. 공정변수별 총 작업시간을 비교하였을 때, 우레탄 도막은 중첩률 $50 \%$, 에너지 밀도 $13.6 \mathrm{~J} / \mathrm{cm}^{2}$ 의 조건에서, 아연 프라이머 도막은 중첩률 $50 \%$, 에 너지 밀도 $9.4 \mathrm{~J} / \mathrm{cm}^{2}$ 의 조건에서 가장 효율적으로 도 장면을 제거할 수 있었다.

Fig. 8은 에너지 밀도에 따른 아연 프라이머로 도장 된 시험편의 레이저 클리닝부 표면 및 단면 사진을 나 타낸다. 아연 프라이머 도막은 모든 조건에서 레이저 1 회 스캔만에 제거된 것을 육안으로 관찰할 수 있다. Fig. 9에 나타낸 클리닝부 표면의 XRD 성분분석 결 과를 통해서도 레이저 클리닝 후 아연 프라이머 도료의 주된 성분인 $\mathrm{Zn}$ 의 피크가 검출되지 않는 것을 확인할 수 있다.

결과적으로 우레탄을 비롯한 후막 도막의 제거에는 높은 에너지 밀도에서 1 회 스캔시 제거량을 증가시킴 으로써 스캔 횟수 감소를 통하여 작업시간을 단축할 수 있다. 반면 아연 프라이머 도막과 같이 박막 도막의 경

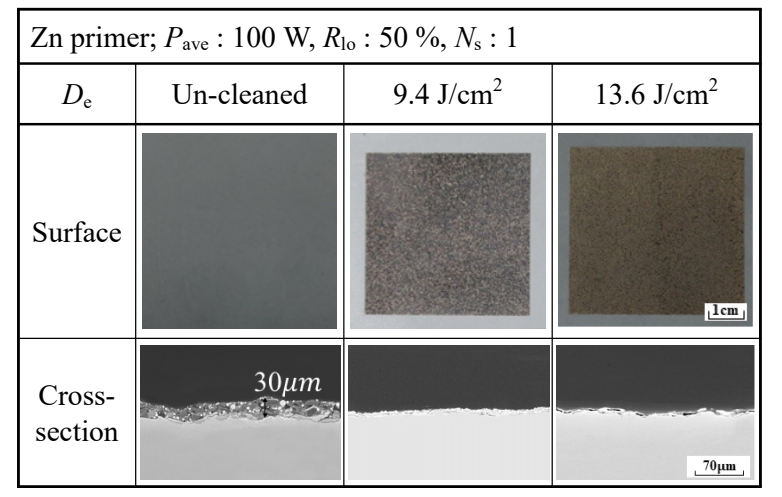

Fig. 8 Laser cleaned surfaces of shop primer painted steel with energy density

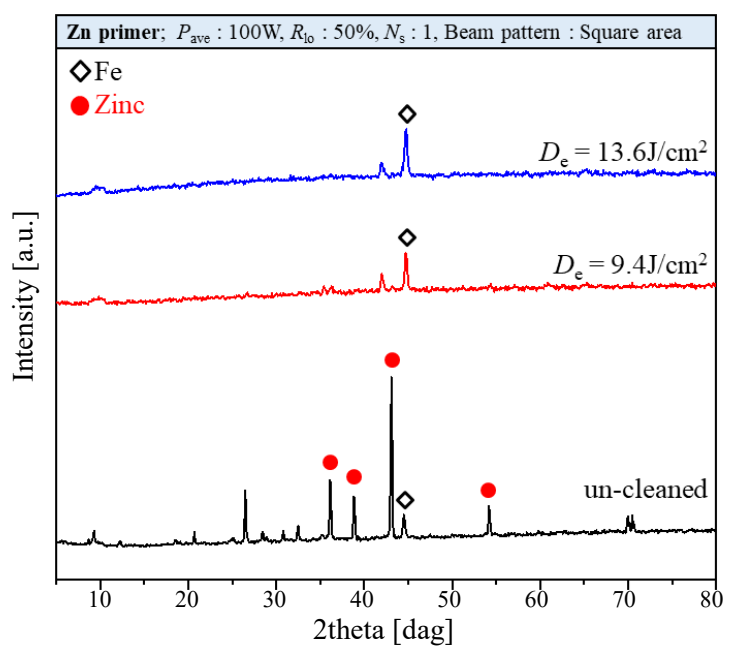

Fig. 9 XRD results of laser cleaned surfaces by energy density 
우 레이저 1회 스캔만에 제거되기 때문에 에너지 밀도 의 영향이 크게 나타나지 않았다. 따라서 도막이 제거 되는 최소 임계 조건을 선정함으로써 효율적인 클리닝 작업이 가능할 것으로 판단하였다.

\section{4. 결 론}

본 논문에서 개발된 휴대용 레이저 클리닝 장비를 사 용하여 서로 다른 도료 및 두께로 도장된 4종류의 시 험편에 대하여 사각형 및 원형의 스캔 모드를 비롯한 클리닝 주요 공정변수에 따른 영향을 분석한 결과, 아 래와 같은 결론을 얻을 수 있었다.

1) 원형의 레이저빔을 사용하여 사각형 및 원형 영 역을 완전하게 클리닝 할 수 있었으며, 레이저 열원에 의한 모재의 기계적 및 열적 손상이 없는 우수한 클리 닝 성능이 관찰되었다. 클리닝 과정에서 사각형 영역을 스캔 할 때에는 도막이 전체적으로 균일하게 제거되었 으며, 원형 영역을 스캔할 경우에는 중심부의 도막이 우선적으로 제거되었다.

2) 스캔 라인 중첩률에 따른 영향을 분석한 결과, 중 첩률이 $50 \%$ 일 경우 가장 빠른 시간에 클리닝 작업을 마칠 수 있었다. 이를 통하여 필요 이상의 중첩률 증가 는 작업시간의 증대를 야기하고, 모재에 열적영향을 미 칠 수 있으므로 최적의 중첩률 선정이 중요함을 알 수 있다.

3) 우레탄과 같이 후막 도막의 제거는 높은 에너지 밀도에서, 아연 프라이머와 같이 박막 도막의 경우에는 에너지 밀도가 상대적으로 낮은 조건에서 효율적인 클 리닝 작업이 가능하였다. 도료별 최적의 클리닝 조건은 에폭시, 방오도료 및 우레탄 시험편의 경우 스캔 라인 중첩률 $50 \%$, 에너지 밀도 $13.6 \mathrm{~J} / \mathrm{cm}^{2}$ 이며, 아연 프 라이머 시험편의 경우 라인 중첩률 $50 \%$, 에너지 밀도 $9.4 \mathrm{~J} / \mathrm{cm}^{2}$ 이다.

4) 결과적으로 평균 출력 $100 \mathrm{~W}$ 휴대용 레이저 클 리닝 장비를 사용하여 조선용 강재 표면의 서로 다른 방청 도막을 완전하게 클리닝 할 수 있었다. 또한 레이 저 클리닝 적용부의 형상에 적합한 스캔모드와 도료 및 두께별 최적의 공정변수를 도출함으로써 기존 기술 대 비 클리닝 성능 향상과 작업시간의 단축도 꾀할 수 있 을 것이다.

\section{후기}

이 논문은 2021년도 정부(산업통상자원부)의 재원으 로 한국산업기술진흥원의 지원의 지원을 받아 수행된 연 구임(P0008763, 2021년 산업전문인력역량강화사업)
ORCID: Ji-Eon Kim: http://orcid.org/0000-0003-0445-5638 ORCID: Moo-Keun Song: http://orcid.org/0000-0001-6799-1302 ORCID: Jong-Myoung Lee: http://orcid.org/0000-0001-8638-5826 ORCID: Jeong-Hun Hyun: http://orcid.org/0000-0002-2643-8284 ORCID: Jong-Do Kim: http://orcid.org/0000-0002-2125-0426

\section{References}

1. J. E. Kim, M. K. Song, J. M. Lee, J. H. Hyun, and J. D. Kim, A Study on the Effect of Overlap Rate on Laser Beam Cleaning Characteristics while Cleaning Paint Using a Low Power Pulsed Laser( I ), J. Weld. Join. 37(5) (2019) 435-440.

https://doi.org/10.5781/JWJ.2019.37.5.1

2. J. E. Kim, M. K. Song, J. M. Lee, J. H. Hyun, and J. D. Kim, A Study on the Effect of Overlap Rate on Laser Beam Cleaning Characteristics while Cleaning Paint Using a Low Power Pulsed Laser( I), J. Weld. Join. 37(5) (2019) 441-447.

https://doi.org/10.5781/JWJ.2019.37.5.2

3. J. E. Kim, M. S. Han, and J. D. Kim, Removal characteristics of shop-primer paint by laser energy density in Q-switching fiber laser cleaning, Modern Phys. Lett. B, 34(7) (2020) 2040042.

https://doi.org/10.1142/S0217984920400424

4. J. E. Kim, M. K. Song, M. S. Han, and J. D. Kim, A study on the application of laser cleaning process in shipbuilding industries using $100 \mathrm{~W}$ fiber laser, J. Mech. Sci. Technol. 35(4) (2021) 1421-1427. https://doi.org/10.1142/S0217979221400063

5. O. A. Kareem and M. A. Harith, Evaluating the use of laser radiation in cleaning of copper embroidery threads on archaeological Egyptian textiles, Appl. Surf. Sci. 254 (18) (2008) 5854-5860.

https://doi.org/10.1016/j.apsusc.2008.03.144

6 . Y. Koh and I. Sarady, Cleaning of corroded iron artefacts using pulsed TEA $\mathrm{CO}_{2}$ and Nd:YAG-lasers, $J$. Cultural Heritage, 4(1) (2003) 129-133. https://doi.org/10.1016/S1296-2074(02)01140-8

7. J. Graf, B. S. Luk'yanchuk, M. Mosbacher, M. H. Hong, C. T. Chong, J. Boneberg, and P. Leiderer, Matrix laser cleaning: a new technique for the removal of nanometer sized particles from semiconductors, Appl. Phys. a-Mater. Sci. Process. 88(2) (2007) 227-230. https://doi.org/10.1007/s00339-007-4017-6

8. M.W. Turner, P. L. Crouse, L. Li, and A. J. E. Smith, Investigation into $\mathrm{CO}_{2}$ laser cleaning of titanium alloys for gas-turbine component manufacture, Appl. Surf. Sci. 252 (2006) 4798-4802.

https://doi.org/10.1016/j.apsusc.2005.06.061

9. G. Zhu, S. Wang, W. Cheng, Y. Ren, and D. Wen, Corrosion and wear performance of aircraft skin after laser cleaning, Opt. Laser Technol. 132 (2020) 106475. https://doi.org/10.1016/j.optlastec.2020.106475

10. Q. H. Tang, D. Zhou, Y. L. Wang, and G. F. Liu, Laser cleaning of sulfide scale on compressor impeller blade, Appl. Surf. Sci. 355 (2015) 334-340. 
https://doi.org/10.1016/j.apsusc.2015.07.128

11. Z. Kuang, W. Guo, J. Li, Y. Jin, D. Qian, J. Ouyang, L. Fu, E. Fearon, R. Hardacre, Z. Liu, and L. Li, Nanosecond fibre laser paint stripping with suppression of flames and sparks, J. Mater. Process. Tech. 266 (2019) 474-483.

https://doi.org/10.1016/j.jmatprotec.2018.11.028

12. Md. Shamsujjoha, S. R. Agnew, M. A. Melia, J. R. Brooks, T. J. Tyler, and J. M. Fitz-Gerald, Effects of laser ablation coating removal (LACR) on a steel substrate: Part 1, Surf. Coat. Technol. 281 (2015) 193-205. https://doi.org/10.1016/j.surfcoat.2015.01.071

13. Md. Shamsujjoha, S. R. Agnew, J. R. Brooks, T. J. Tyler, and J. M. Fitz-Gerald, Effects of laser ablation coating removal (LACR) on a steel substrate: Part 2, Surf. Coat. Technol. 281 (2015) 206-214.

https://doi.org/10.1016/j.surfcoat.2015.02.034
14. G. X. Chen, T. J. Kwee, K. P. Tan, Y. S. Choo, and M. H. Hong, High-Power Fibre Laser Cleaning for Green Shipbuilding, J. Laser Micro/Nanoeng. 7(3) (2012) 249-253. https://doi.org/10.2961/JLMN.2012.03.0003

15. D. M. D’Addona, S. Genna, A. Giordano, C. Leone, D. Matarazzo, and L. Nele, Laser Ablation of Primer During the Welding Process of Iron Plate for Shipbuilding Industry, Procedia CIRP, 33 (2015) 464-469. https://doi.org/10.1016/j.procir.2015.06.055

16. Z. Tian, Z. Lei, X. Chen, and Y. Chen, Evaluation of laser cleaning for defouling of marine biofilm contamination on aluminum alloys, Appl. Surf. Sci. 499 (2020) 144060 .

https://doi.org/10.1016/j.apsusc.2019.144060 